\title{
Hereditary melanoma: a five-year study of Brazilian patients in a cancer referral center - phenotypic characteristics of probands and pathological features of primary tumors*
}

\author{
Bianca Costa Soares de Sá ${ }^{1}$ \\ Elimar Elias Gomes ${ }^{1}$ \\ João Pedreira Duprat ${ }^{1}$
}

\author{
Luciana Facure Moredo ${ }^{1}$ \\ Erica Sara Souza de Araújo ${ }^{1}$
}

DOI: http:/ / dx.doi.org/10.1590/abd1806-4841.20186201

\begin{abstract}
BACKGROUND: Approximately five to 10\% of all melanomas occur in families with hereditary predisposition and the main high-risk melanoma susceptibility gene is the CDKN2A.

ОвлестіVEs: To describe, after a five-years study, the clinical data of patients (probands) from familial melanoma kindreds, and the pathological characteristics of their melanoma.

METHODS: The inclusion criteria were melanoma patients with a family history of melanoma or pancreatic cancer (first- or second-degree relatives) or patients with multiple primary melanomas (MPM).

RESULTS: A total of 124 probands were studied, where 64 were considered familial cases and 60 MPM. Mean age at diagnosis was 50 years. Our results show that the following characteristics were prevalent: skin phototype I/II (89.5\%), sunburn during childhood (85.5\%), total number of nevi $\geq 50$ (56.5\%), Breslow thickness $\leq 1.0 \mathrm{~mm}(70.2 \%)$, tumors located on the trunk $(53.2 \%)$ and superficial spreading melanomas $(70.2 \%)$.

STUDY Limitations: Analyses of probands' relatives will be demonstrated in future publication.

CONCLUSIONS: Our findings are in agreement with previous familial melanomas reports. Fifteen new melanomas in 11 patients were diagnosed during follow up, all of which were $\leq 1.0 \mathrm{~mm}$. This is the largest dataset of Brazilian melanoma prone kindreds to date, thus providing a complete database for future genetic studies.
\end{abstract}

Keywords: Inheritance patterns; Melanoma; Neoplastic syndromes, Hereditary; Phenotype; Risk factors; Surveillance

\section{INTRODUCTION}

Aetiology of cutaneous melanoma $(\mathrm{CM})$ is related to genetic, phenotypic and environmental risk factors. The main environmental factor for melanoma is exposure to ultraviolet radiation (UVR) and its effect on melanoma genesis is closely related to host pigmentation characteristics such as fair skin, sun sensitivity, red/ blonde hair color, blue eyes and freckling. Another risk factor is the presence of multiple nevi and atypical nevi. However, the most important risk factors are family and personal history of melanoma. ${ }^{1-4}$

Approximately five to $10 \%$ of all melanomas occur in families with hereditary predisposition. The familial melanoma syndrome (FMS) is defined by the presence of two or more cases of melanoma in first- or second-degree relatives; or the presence of two or more melanomas in the same individual (multiple primary melanomas - MPM). However, in areas with a moderate to high incidence of melanomas, FMS is diagnosed in individuals with three or more primary melanomas and in families with three or more cases of melanomas in first- or second-degree relatives. ${ }^{5-8}$

To date, cyclin-dependent kinase inhibitor $2 A$ (CDKN2A) is the main high-risk FMS susceptibility gene. The $C D K N 2 A$ gene encodes two distinct proteins from alternative first exons ( $1 \alpha$ and $1 \beta), \mathrm{p} 16 \mathrm{IN}$ K4a and p14ARF, respectively. Both act as tumor suppressors by inhibiting cell cycle through different pathways: p16INK4a is related

\footnotetext{
Received 27 June 2016.

Accepted 16 March 2017.

* Work conducted at the Skin Cancer Department, AC Camargo Cancer Center, São Paulo (SP), Brazil.

Financial support: None.

Conflict of interest: None.

1 Skin Cancer Department, AC Camargo Cancer Center, São Paulo (SP), Brazil.
}

MAILING ADDRESS:

Bianca Costa Soares de Sá

E-mail: bianca.sa@terra.com.br 
to retinoblastoma and p14INK to p53. ${ }^{9}$ Mutations in the CDKN2A gene have been found in up to $10 \%$ of families with two melanoma cases and in 30 to $40 \%$ of families with three or more cases. ${ }^{10,11}$

Studies have shown an increased risk of developing pancreatic carcinoma in European and North American families with $C D$ KN2A mutations. ${ }^{12}$ Additionally, FMS may be associated with other cancers, such as central nervous system tumors, uveal melanoma, lung and breast carcinomas. ${ }^{12-15}$

We have been monitoring families at high risk for cutaneous melanoma since June 2010. In this study, we aim to describe, after five years of surveillance, the clinical and pathological characteristics of melanoma patients (probands) from familial melanoma kindreds.

\section{METHODS}

Patients were referred to the Familial Melanoma Clinic from the Skin Cancer Department of AC Camargo Cancer Center, São Paulo, Brazil, based on inclusion criteria such as: 1-Melanoma patients with at least one first- or second-degree relative that has or has had melanoma or pancreatic cancer - familial melanoma group (FM); 2-Patients with two or more melanomas - multiple primary melanoma group (MPM); 3-Cancer confirmation from both melanoma patients and their relatives (pathology report, medical records and/or death certificates). A form was filled out by the patients' attending physician or nurse (BCSS, LFM or EEG).

The following variables were considered in this study: 1-Demographic and phenotypic characteristics - gender, age at diagnosis, eye and hair color, skin phototype according to Fitzpatrick (I-IV), total number of nevi, presence of clinically atypical nevi (diameter $\geq 5 \mathrm{~mm}$; when a papular component was present, the mole should also contain a macular component and at least two of the three characteristics: variegated color, asymmetry or irregular borders), atypical mole syndrome (AMS) according to the scoring system proposed by Newton et al. (score $\geq 3$ ) ${ }^{16,17}$, freckle density in arms and shoulders (ranging from 0 to 100 in intervals of 20, where $0=$ no freckling, $20 / 40=$ low freckle density, and 60/80/100 = high freckle density) $;{ }^{18}$, iris pigmentation; 2- Lifetime history of sunburns - childhood and adolescence, adult age or both; 3. Specific characteristics of melanomas - date of excision, anatomical location (head/neck, trunk, upper and lower limbs), histological subtype (superficial spreading, nodular, lentigo malignant, acral) and Breslow thickness; 4 . Family history of melanoma, pancreatic cancer and central neural system tumors; 5 . Oncological history - non-melanoma cancers of probands.

Throughout the course of the program, probands and their relatives were given the opportunity to participate in a regular screening program that included total skin examination every six (probands and relatives with melanoma) or twelve months (relatives with no history of melanoma), body mapping, digital dermoscopy follow-up of melanocytic lesions and annual revision of family pedigree. Additionally, melanoma patients were submitted to regular follow up according to its clinical stage.

The study was approved by the Research Ethical Committee of AC Camargo Cancer Center, São Paulo, Brazil (2076/15).

\section{Statistical Analyses}

Descriptive analyses using percentages was performed for categorical variables and mean, minimum, maximum and standard deviation (SD) for continuous variables.

Fisher exact tests and chi-square tests were used to evaluate differences in phenotypic characteristics and UV exposure between AMS and non-AMS probands and FM and MPM groups. Differences in age at diagnosis between the groups mentioned above were tested for significance using Mann-Whitney tests. All tests were two sided and $P<0.05$ was considered statiscally significant. All statistical analyses were carried out with the GraphPad PRISM (GraphPad Software Inc., La Jolla, California, USA) statistics software package.

\section{RESULTS}

During the period from June 2010 to June 2015, of all patients referred to the Familial Melanoma Clinic, 124 probands fulfilled the inclusion criteria (63 men and 61 women). The mean age at diagnosis was 50 years (SD 13; range 15-85 years). Nine patients were diagnosed at age 30 or younger but most cases occurred in the fifth decade of life (29.0\%).

Fifty-one patients had only one melanoma (41.1\%), 55 had two melanomas $(44.4 \%)$ and 18 had three or more melanomas (14.5\%). MPM with no family history of melanoma was found in 60 cases (48.4\%). Among the 64 probands with family history, thirteen $(20.3 \%)$ also had multiple primary melanomas.

Most patients were classified as phototype I and II (89.5\%) and had dark hair and dark eyes (50.8\% and $52.4 \%$, respectively). Sunburn during childhood was reported in $85.5 \%$ of cases and $64.5 \%$ had a high freckle density on shoulders. Regarding total number of nevi, $56.5 \%$ had $\geq 50$ and $28.2 \%$ of all patients fulfilled the AMS criteria (Table 1).

In familial cases, 58 patients had a family history of melanoma (84.5\% first-degree relatives and $15.5 \%$ second-degree relatives) and only six had a family history of pancreatic cancer (five first-degree relatives and one second-degree relative). Only two patients had a family history of both melanoma and pancreatic cancer. We found $50(86.2 \%)$ probands with only one family member with melanoma, six (10.3\%) with two family members and two (3.5\%) with three family members affected.

The mean Breslow thickness was 0.62mm (SD 0.65; range $0-6.4 \mathrm{~mm})$. Most tumors $(70.2 \%)$ were thin melanomas $(\leq 1.0 \mathrm{~mm})$. The most frequent anatomical site was the trunk (53.2\%) followed by lower limbs $(24.2 \%)$. The predominant histological subtype was superficial spreading melanoma (70.2\%; Table 2).

During follow-up, 15 melanomas were diagnosed in 11 patients, all of which were early melanomas (seven in situ melanomas and eight melanomas $<1.0 \mathrm{~mm}$ ).

There were only three cases with family history of central neural system tumor. We found non-melanoma cancers in 37 probands: 24 cases of basal cell carcinomas, eight cases of spindle cell carcinomas, two breast cancers, two prostate cancers and three thyroid cancers. Five patients had had two different non-melanoma cancers.

Phenotypic characteristics, pathological features of melanomas and age at diagnosis did not differ significantly between AMS 


\begin{tabular}{|c|c|c|}
\hline \multicolumn{2}{|l|}{ Variables } & \multirow{2}{*}{$\frac{\mathbf{N}(\%)}{111(89.5)}$} \\
\hline Skin phototype & $\mathrm{I} / \mathrm{II}$ & \\
\hline & III/IV & $13(10.5)$ \\
\hline \multirow[t]{3}{*}{ Eye color } & blue & $23(18.6)$ \\
\hline & green & $38(30.6)$ \\
\hline & brown/ black & $63(50.8)$ \\
\hline \multirow[t]{3}{*}{ Hair color } & red & $13(10.5)$ \\
\hline & blond & $46(37.1)$ \\
\hline & brown & $65(52.4)$ \\
\hline \multirow[t]{3}{*}{ Sunburn } & childhood & $106(85.5)$ \\
\hline & adult age & $61(49.2)$ \\
\hline & both & $53(45.7)$ \\
\hline \multirow[t]{4}{*}{ Freckle density ARMS } & $\varnothing$ & $29(23.4)$ \\
\hline & low & $67(54.0)$ \\
\hline & high & $25(20.2)$ \\
\hline & missing data & $3(2.4)$ \\
\hline \multirow[t]{4}{*}{ Freckle density SHOULDERS } & $\varnothing$ & $7(5.7)$ \\
\hline & low & $34(27.4)$ \\
\hline & high & $80(64.5)$ \\
\hline & missing data & $3(2.4)$ \\
\hline \multirow[t]{3}{*}{ Indoor tanning } & yes & $20(16.1)$ \\
\hline & no & $102(82.3)$ \\
\hline & missing data & $2(1.6)$ \\
\hline \multirow[t]{3}{*}{ Atypical nevi } & yes & $56(45.2)$ \\
\hline & no & $64(51.6)$ \\
\hline & missing data & $4(3.2)$ \\
\hline \multirow[t]{4}{*}{ Nevi count } & $\varnothing$ & $2(1.6)$ \\
\hline & $0-49$ & $49(39.5)$ \\
\hline & $\geq 50$ & $70(56.5)$ \\
\hline & missing data & $3(2.4)$ \\
\hline \multirow[t]{3}{*}{ AMS } & yes & $35(28.2)$ \\
\hline & no & $86(69.4)$ \\
\hline & missing data & $3(2.4)$ \\
\hline \multirow[t]{3}{*}{ Iris pigmentation } & yes & $20(16.1)$ \\
\hline & no & $100(80.7)$ \\
\hline & missing data & $4(3.2)$ \\
\hline
\end{tabular}

\begin{tabular}{|c|c|c|}
\hline Variables & Number & $\%$ \\
\hline \multicolumn{3}{|l|}{ Breslow thickness } \\
\hline$\leq 1.0 \mathrm{~mm}$ & 87 & 70.2 \\
\hline$>1.0 \mathrm{~mm}$ & 24 & 19.3 \\
\hline missing data & 13 & 10.5 \\
\hline \multicolumn{3}{|l|}{ Anatomic location } \\
\hline head/neck & 8 & 6.5 \\
\hline trunk & 66 & 53.2 \\
\hline upper limbs & 18 & 14.5 \\
\hline lower limbs & 30 & 24.2 \\
\hline missing data & 2 & 1.6 \\
\hline \multicolumn{3}{|l|}{ Histological type } \\
\hline SSM & 87 & 70.2 \\
\hline NM & 4 & 3.2 \\
\hline LMM & 3 & 2.4 \\
\hline Acral & 2 & 1.6 \\
\hline Others & 2 & 1.6 \\
\hline Unclassified or unknown & 26 & 21.0 \\
\hline
\end{tabular}

SSM- superficial spreading melanoma NM-nodular melanoma

LMM-lentigo malignant melanoma

probands and the pathological features of their melanomas. Early onset of the disease is an important feature of hereditary cancer. In this study, mean age at diagnosis was 50 years, nearly 10 years earlier than in general populations, although $7.3 \%$ of patients had been diagnosed even earlier, at the age of 30 or younger. ${ }^{19,20}$ We found no differences in age at diagnosis between AMS and non-AMS patients and between FM and MPM patients. In accordance to previous reports, a high number of patients reported childhood sunburns (85.5\%). ${ }^{20,21}$ Most probands showed total nevi count $\geq 50$ (45.2\%) and a high freckle density on shoulders (64.5\%) and trunk was the most prevalent tumor anatomic location (53.2\%). As described recently in familial melanoma, these results suggest that the nevus pathway could be responsible for melanoma pathogenesis in these patients, which is associated to somatic BRAF mutations. ${ }^{22-24}$

Unfortunately, histology of many melanomas was either unclassified or classification could not be accessed from patients' records $(21 \%)$. Among those that were classified, the most frequent histological type was superficial spreading melanoma (70.2\%) with a very low proportion of acral (1.6\%) and lentigo malignant melanoma $(2.4 \%)$, as described in previous familial melanoma studies. ${ }^{22,25,26}$ As reported before in familial melanoma kindreds, most patients $(70.2 \%)$ presented thin melanomas. ${ }^{21,22}$

Once all probands were enrolled in the screening program, we were able to diagnose 15 new melanomas in 11 patients, all of which were $<1.0 \mathrm{~mm}$. The early detection enabled complete removal of these melanomas at initial stages of the disease, improving patients' prognosis. 


\section{CONCLUSIONS}

Our findings are in agreement with previous reports that show certain phenotypic and pathological characteristics in familial melanomas, such as history of sunburns during childhood, younger age at diagnosis when compared with the general population, greater number of nevi, greater frequency of superficial spreading melanomas and lower frequency of lentiginous melanomas, and a greater incidence of tumors on the trunk.
This is the largest dataset of Brazilian melanoma prone kindreds to date, thus providing a complete database for future genetic studies.

Currently, the Familial Melanoma Clinic from the Skin Cancer Department of AC Camargo Cancer Center remains active and monitors more than 300 melanoma prone families in their program. $]$

\section{REFERENCES}

1. larc Monographs on the Evaluation of Carcinogenic Risks to Humans, No. 55 IARC Working Group on the Evaluation of Carcinogenic Risk to Humans. World Health Organization. Solar and ultraviolet radiation. Iarc Lyon (FR): International Agency for Research on Cancer; 1992.

2. Garbe C, Büttner P, Weiss J, Soyer HP, Stocker U, Krüger S, Roser M, et al. Associated factors in the prevalence of more than 50 common melanocytic nevi, atypical melanocytic nevi, and actinic lentigines: multicenter case-control study of the Central Malignant Melanoma Registry of the German Dermatological Society. $J$ Invest Dermatol. 1994;102:700-5.

3. Bliss JM, Ford D, Swerdlow AJ, Armstrong BK, Cristofolini M, Elwood JM, et al. Risk of cutaneous melanoma associated with pigmentation characteristics and freckling: systematic overview of 10 case-control studies. The Internationa Melanoma Analysis Group (IMAGE). Int J Cancer. 1995;62:367-76.

4. Bränström R, Chang YM, Kasparian N, Affleck P, Tibben A, Aspinwall LG, et al. Melanoma risk factors, perceived threat and intentional tanning: an international online survey. Eur J Cancer Prev. 2010;19:216-26.

5. Platz A, Ringborg U, Hansson J. Hereditary cutaneous melanoma. Semin Cancer Biol. 2000;10:319-26.

6. Hansson J. Familial melanoma. Surg Clin North Am. 2008:88:897-916, viii.

7. Leachman SA, Carucci J, Kohlmann W, Banks KC, Asgari MM, Bergman W, et al. Selection criteria for genetic assessment of patients with familial melanoma. J Am Acad Dermatol. 2009;61:677.e1-14

8. Puig S, Potrony M, Cuellar F, Puig-Butille JA, Carrera C, Aguilera P, et al. Characterization of individuals at high risk of developing melanoma in Latin America: bases for genetic counseling in melanoma. Genet Med. 2016;18:727-36.

9. de Snoo FA, Hayward NK. Cutaneous melanoma susceptibility and progression genes. Cancer Lett. 2005;230:153-86.

10. Goldstein AM, Chan M, Harland M, Hayward NK, Demenais F, Bishop DT, et al. Melanoma Study Group; Melanoma Genetics Consortium (GenoMEL). Features associated with germline CDKN2A mutations: a GenoMEL study of melanomaprone families from three continents. J Med Genet. 2007;44:99-106.

11. de Ávila AL, Krepischi AC, Moredo LF, Aguiar TF, da Silva FC, de Sá BC, et al. Germline CDKN2A mutations in Brazilian patients of hereditary cutaneous melanoma. Fam Cancer. 2014;13:645-9.

12. Goldstein AM, Chan M, Harland M, Gillanders EM, Hayward NK, Avril MF, et al. Melanoma Genetics Consortium (GenoMEL). High-risk melanoma susceptibility genes and pancreatic cancer, neural system tumors, and uveal melanoma across GenoMEL. Cancer Res. 2006;66:9818-28.

13. Azizi E, Friedman J, Pavlotsky F, Iscovich J, Bornstein A, Shafir R, et al. Familia cutaneous malignant melanoma and tumors of the nervous system. A hereditary cancer syndrome. Cancer. 1995;76:1571-8.
14. Vasen HF, Gruis NA, Frants RR, van Der Velden PA, Hille ET, Bergman W. Risk of developing pancreatic cancer in families with familial atypical multiple mole melanoma associated with a specific 19 deletion of p16 (p16-Leiden). Int J Cancer. 2000;87:809-11.

15. Potrony M, Puig-Butillé JA, Aguilera P, Badenas C, Carrera C, Malvehy J, et al. Increased prevalence of lung, breast, and pancreatic cancers in addition to melanoma risk in families bearing the cyclin-dependent kinase inhibitor $2 \mathrm{~A}$ mutation: implications for genetic counseling. J Am Acad Dermatol. 2014;71:888-95.

16. Newton JA, Bataille V, Griffiths K, Squire JM, Sasieni P, Cuzick J, et al. How common is the atypical mole syndrome phenotype in apparently sporadic melanoma? J Am Acad Dermatol. 1993;29:989-96

17. Silva JH, Sá BC, Avila AL, Landman G, Duprat Neto JP. Atypical mole syndrome and dysplastic nevi: identification of populations at risk for developing melanoma - review article. Clinics (Sao Paulo). 2011:66:493-9.

18. McLean DI, Gallagher RP. "Sunburn" freckles, café-au-lait macules, and other pigmented lesions of schoolchildren: the Vancouver Mole Study. J Am Acad Dermatol. 1995;32:565-70.

19. Ali Z, Yousaf N, Larkin J. Melanoma epidemiology, biology and prognosis. EJC Suppl. 2013:11:81-91.

20. Chiarugi A, Nardini P, Crocetti E, Carli P, De Giorgi V, Borgognoni L, et al. GIPMe Participants Centres. Familial and sporadic melanoma: different clinical and histopathological features in the Italian population - a multicentre epidemiological study - by GIPMe (Italian Multidisciplinary Group on Melanoma). J Eur Acad Dermatol Venereol. 2012;26:194-9

21. Márquez-Rodas I, Martín González M, Nagore E, Gómez-Fernández C, AvilésIzquierdo JA, Maldonado-Seral C, et al. Spanish Multidisciplinary Group of Melanoma (GEM). Frequency and characteristics of familial melanoma in Spain: the FAM-GEM-1 Study. PLoS One. 2015;10:e0124239.

22. Aguilera P, Malvehy J, Carrera C, Palou J, Puig-Butillé JA, Alòs L, et al. Clinica and Histopathological Characteristics between Familial and Sporadic Melanoma in Barcelona, Spain. J Clin Exp Dermatol Res. 2014;5:231.

23. Whiteman DC, WattP, Purdie DM, Hughes MC, Hayward NK, Green AC. Melanocytic nevi, solar keratoses, and divergent pathways to cutaneous melanoma. J Natl Cancer Inst. 2003:95:806-12.

24. Whiteman DC, Pavan WJ, Bastian BC. The melanomas: a synthesis of epidemiological, clinical, histopathological, genetic, and biological aspects, supporting distinct subtypes, causal pathways, and cells of origin. Pigment Cell Melanoma Res. 2011;24:879-97.

25. Nagore E, Botella-Estrada R, Garcia-Casado Z, Requena C, Serra-Guillen C, Llombart B, et al. Comparison between familial and sporadic cutaneous melanoma in Valencia, Spain. J Eur Acad Dermatol Venereol. 2008:22:931-6.

26. van der Rhee Jl, Krijnen P, Gruis NA, de Snoo FA, Vasen HF, Putter H, et al. Clinical and histologic characteristics of malignant melanoma in families with a germline mutation in CDKN2A. J Am Acad Dermatol. 2011;65:281-8.

Erica Sara Souza de Araújo (iD) ORCID 0000-0002-4464-7493

João Pedreira Duprat Neto ORCID 0000-0001-8968-4506

$\begin{array}{ll}\text { Bianca Costa Soares de Sá } & \text { (iD) ORCID 0000-0001-6572-3283 } \\ \text { Luciana Facure Moredo } & \text { (iD) ORCID 0000-0003-3589-7041 } \\ \text { Elimar Elias Gomes } & \text { (iD) ORCID 0000-0003-2637-7749 }\end{array}$

How to cite this article: Soares de Sá BC, Moredo LF, Gomes EE, de Araújo ESS, Duprat JP. Hereditary melanoma: a five-year study of Brazilian patients in a cancer referral center - phenotypic characteristics of probands and pathological features of primary tumors. An Bras Dermtatol. 2018;93(3): 337-40. 